\title{
Leadership Management and Youth Competencies in the Administration of Public Policy in Indonesia
}

\author{
Submitted 10/04/20, 1st revision 14/05/20, 2nd revision $27 / 06 / 20$, accepted $30 / 07 / 20$
}

\author{
Andries Lionardo ${ }^{1}$, Chairun Nasirin ${ }^{2}$
}

\begin{abstract}
:
Purpose: This study was conducted to determine the leadership style and competence of the leaders according to the Indonesian youth perspective. Besides, the study also identified differences in leadership style and leadership competencies according to the youth perspective based on the level of education.

Approach/Methodology/Design: The survey conducted used a questionnaire with 800 Indonesian youth. SPSS 25 and AMOS 18 software were used to analyze the study findings.

Findings: The results show that there is a difference in leadership style and leadership competence, according to the Indonesian youth perspective, based on the level of education. The findings of the study show that there is no significant difference in the style of leadership and commitment of the facilitator according to the perspective of Indonesian youth based on the level of education. This shows that Indonesian youth have a similar outlook on leadership style and competence. The findings show that youth with a level of education as students in the school where participation style leadership positively affects emotional ability, while leadership style leads to a negative impact on emotional competence. The results of the study also show that from the perspective of youth studying at the university level, leadership style has a positive effect on emotional competence. While leadership styles support, participation and achievement-oriented leadership styles negatively affect emotional and spiritual capability.

Practical Implications: The findings of this study have implications for national leaders to be able to use effective leadership styles in nation-building and to increase their capacity to achieve the direction of national development.

Originality/value: The results identify the influence of leadership style on the emotional and spiritual competence of leaders according to the Indonesian youth perspective.
\end{abstract}

Keywords: Commitment, leadership style, youth, Indonesia, education, politics.

JEL: $G 24$.

Paper Type: Research article.

\footnotetext{
${ }^{1}$ Faculty of Social and Political Sciences, University of Sriwijaya, Indonesia, e-mail: andries_lionardo@yahoo.co.id

${ }^{2}$ Department of Health Administration, College of Health Sciences (STIKES) Mataram, Indonesia, e-mail: chairun-nasirin@stikesmataram.ac.id
} 


\section{Introduction}

The benchmark of progress in Indonesia is leaders. Good leaders have a huge influence on the country's progress. There are few problems that arise in society as neglect of leaders, while on the other hand, people are people who do not understand the problem. The idea of leadership must be in the form of social relations that are defined by the distance or proximity of a person to the basic values of the political community. In other words, the closer a person becomes the center of political power, the higher he or she is in the social hierarchy. In an employee's environment, leadership means that someone in the higher hierarchy is the "leader" for those in the lower hierarchy. As a "nation," society is not only confronting new political consciousness that transcends ethnic boundaries but also perpetuates values-based continuity that is absorbed from historical experience. Leaders are inseparable from human life and play an important role in running the organization's wheels. In fact, leaders with their leadership determine the progress or retreat of the organization, and in a broader context, determine the downfall and the erise of the nation. This includes categories and channels of leadership.

Leadership style is a manifestation of a leader's behavior, which involves his ability to lead. These forms usually form certain patterns or shapes. This understanding of leadership style is in line with the views expressed by Boukis et al. (2020). Both stated that the overall pattern of leader action as perceived or referred to by subordinates, is known as a leadership style. Leadership style is the behavior or method chosen and used by leaders in influencing the thoughts, feelings, attitudes, and behaviors of members of their subordinate organizations (Rehman et al., 2020). According to Kearney et al. (2019), leadership style is the way leaders interact with their subordinates. Meanwhile, other opinions suggest that leadership style is the behavior (words and actions) of a leader perceived by others (Cheung et al., 2020). One of the most reliable theories is the goal-oriented theory, which is a leadership model developed by the purpose of the road goal theory that is the leader's duty to help their members to achieve their goals and to provide direction and support or both to ensure their goals align with the goals of the group or organization as a whole.

Fitzsimons et al. (2016) tested the path of goal theory using two leadership styles, namely, command leader and support leader. The results show a significant influence on leadership and job satisfaction. Dumitriu et al. (2014) also examined the impact of task complexity and locus of control on the relationship between leadership style and auditor job satisfaction, as team leaders should be able to adapt their style of leadership style to situational factors as there is no effective leadership style for all situations or conditions. This study aimed to identify the influence of leadership style on the emotional and spiritual competence of leaders according to the Indonesian youth perspective. Besides, this study also identified differences in leadership style and leadership competencies based on the level of youth education. 


\section{Literature Review}

There is an expectation that future leaders will meet and have the following conditions such as providing vision, direction, and purpose. An effective leader brings depth passion, perspective, and meaning in the process of defining his or her goals and objectives. Every effective leader realizes what he or she is doing. The time and effort devoted to work require commitment and appreciation, trust in and from the Leader. Trust and openness are important components of leadership. When we are honest about the limitations of knowledge for which there is no overall answer, we gain the understanding and appreciation of others. A leader who creates a climate of openness in his leadership is a leader who can overcome obstacles in the form of concerns that cause his people to direct the wrong things for his leadership. When leaders share information about their policies, leaders treat openness as one of the benchmarks of their performance (Nasirin and Asrina, 2020; Bin Kamari et al., 2019; Nasirin, 2020). Other expectation is the capability for delivering results through action, risk, curiosity, and courage. Future leaders are revenue-oriented leaders, looking at themselves as catalysts - hoping to achieve great results, but realizing they can do little to no effort from others. Such leaders bring the spirit, resources, risk tolerance, discipline of "entrepreneurs."

Character is the key to becoming a successful leader. A leader must be able to set an example for others, especially his team members. It is a character that will determine your success or failure in various aspects of life. There are no exceptions in the political world. Success or failure in leadership will be reflected in teamwork and the extent to which the organization is developing. There are ten main characters that a leader must possess. These characters are proactive, flexible, communicative, open, intelligent, confident, high initiative, organized, evaluative, and rewarding.

Competence is a necessary characteristic of doing something, and leadership competence is seen as an experience, wisdom, and ability to perform tasks effectively (Pham and Kim, 2019; Shao, 2018; Latunreng and Nasirin, 2019). Competence as the basic characteristics of individuals needed to perform a task, for example, skills, knowledge, attitudes, beliefs, motives, and attributes, which enables excellent job creation in line with the organization's strategic functions. Effective leaders are competent leaders who need to be identified as it is the foundation for effective management leadership. Therefore, to ensure organizational excellence, it is important that competent leaders are appointed to lead the organization (Hashemy et al., 2016). Besides, a leader must also have the desire to lead and be able to acquire the basic skills needed to lead the organization. All of these features are in line with the views identified competence as a form of behavior that requires emotional, social, and cognitive intelligence. Leadership competence can be gained by seeking guidance from experienced leaders and participating in leadership preparation programs that emphasize real-world experience (Bouwmans et al., 2017). This means that competent leaders can be created through a well-planned leader development program and implemented through the education, experience, and guidance of experienced leaders. 
Figure 1. Conceptual Framework

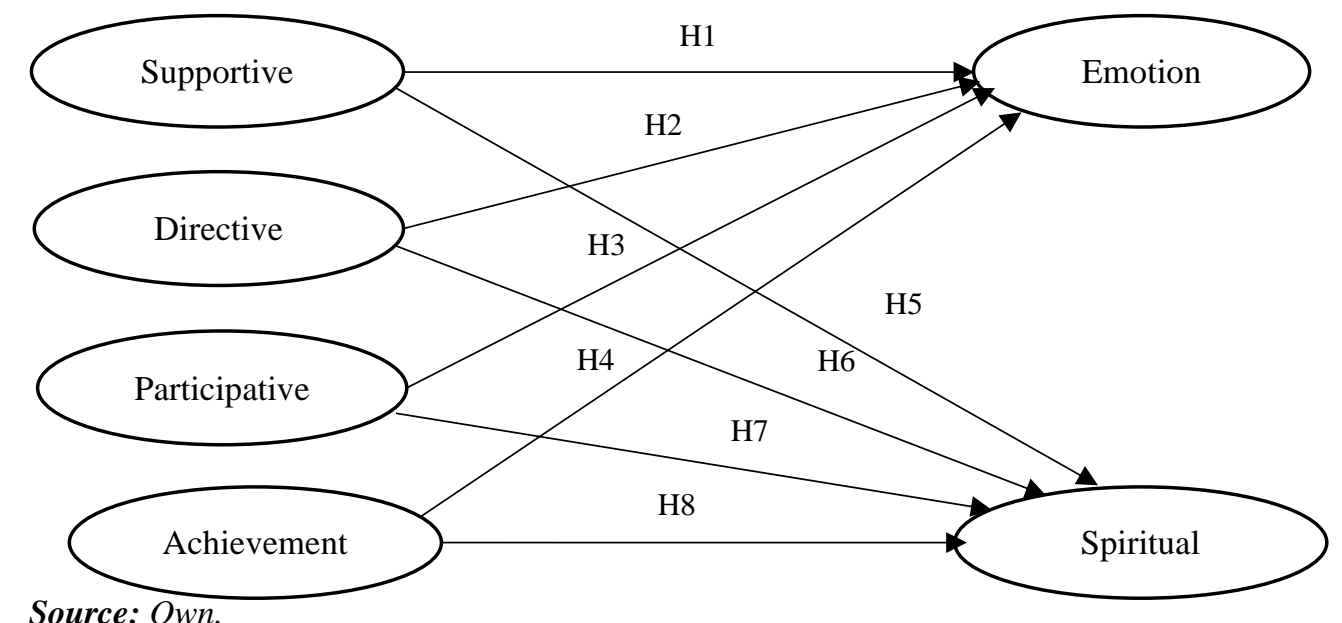

\section{Methodology}

Quantitative research methods allow researchers to explain research problems by explaining the relationships between variables, specializing in variables, hypotheses, and specific research questions, and testing theories (Creswell, 2012). In addition, correlation studies also help to explain phenomena and predict the results of possible studies. There are several benefits to using a correlation study design. The data for this study were collected through the questionnaire form. According to questionnaires, it enables the generalization of findings to larger populations, which is also in line with the objective of quantitative research. Also, questionnaires are commonly used to collect survey information, present structured numerical data, be conducted without the existence of researchers, and are easy to analyze (Figure 1).

\section{Participants}

This study of sampling method used an approach to decision making on sample size based on population size. A population selected the sample more than the recommendations provided in the sample scheduling of 800 respondents consisting of youths between the ages of 19 and $25.446(55.8 \%)$ were male, and $354(44.3 \%)$ were female. 302 (37.8\%) youth were employed, 250 (31.3\%) were working youth, and 248 $(31.0 \%)$ were unemployed. There are many proposed methods in this regard, such as at least 50,200 , or 250 to 500 respondents. Interestingly, the minimum sample size for the SEM model also depends on several factors, including model complexity and commonalities. When the number of factors is greater than seven, the sample size requirement may exceed 500. However, after the data cleansing process, this study used a data set of 800 respondents. This sample size has met the criteria set by several researchers. 


\section{Measurement}

The instruments in this study are divided into three sections: the first is the demographic profile of the study sample, the second part is the leadership style survey, and the third part is the leadership commitment questionnaire. Prior to the use of the instrument, the validity and reliability of the instrument were carried out. Fraenkel and Wallen (2009) state that validity is defined as the appropriateness, usefulness, accuracy, and usefulness of a researcher's conclusions. Validity is also the level at which all evidence supports the interpretation intended for test scores for the objectives proposed by a data-based researcher (Creswell, 2012; Fraenkel and Wallen, 2009).

In this study, there are two validities, namely content validity and construct validity. Content validity refers to the extent to which the questions in the instrument and the scores of those questions represent the content (Creswell, 2012). The validity of the content in this study is by reference to three experts. Corrections and improvements to the questionnaire were carried out. Furthermore, the validity of a construct is the determination of the significance, meaning, purpose, and use of scores of an instrument (Creswell, 2012). In this study, validation factor analysis (CFA) was performed to determine the validity of the instrument construct, which also meant to identify any underlying relationship between items at scale.

Each questionnaire used a 7-point Likert scale $(1=$ Extraordinary, $2=$ Negative, $3=$ Somewhat Preferential, $4=$ Negative, $5=$ Moderate, $6=$ Preferential, and 7 Highly Liked). A pilot study of a survey measuring leadership styles and competencies was conducted involving 200 Indonesian youth. According to pilot studies are small-scale studies that are conducted before actual studies are conducted to look at the validity of a study. The results of a pilot study with reliability for leadership style instruments are 0.95 , and their confidence is 0.87 . Furthermore, composite reliability-CR values (greater than 0.60) and average extracted variance (AVE) (greater than 0.50).

\section{Data Analysis}

The study uses descriptive statistics and inferences to achieve the research objectives. The SPSS 25 software was used to determine leadership style differences and competencies, according to the Indonesian youth perspective. The one-way Manova test is used to identify differences in leadership styles and competencies based on youth education standards. The structural equation modeling (SEM) technique was used to explain the relationship between observed variables and latent variables. Influence of leadership style on competency using the SEM test with the help of AMOS software 18. Goodness of fit was assessed using chi-square $\left(\chi^{2}\right)(p>0.05)$, comparative fit index (CFI>0.90), Tucker Lewis index (TLI>0.90) ( Aug, 2012). CFI is part of the incremental index compatibility in SEM, which measures the relative increase in a fit of the hypothesized model compared to the baseline model. 


\section{Results}

\section{Leadership style differences and competition based on educational level:}

A one-way Manova test was conducted to identify differences in leadership style and competition based on educational level. Box'M test $(F=4.445, p>0.05)$ showed that all dependent variables had the same variance for each group and allowed to use oneway Manova tests. The results of the Wilk Lambda test $(\mathrm{F}=0.997$, sig $=0.317, \mathrm{p}>$ 0.05 ) indicated that there was no difference in leadership style and competition based on educational level. The differences for each variable are as shown in Table 1 below.

Table 1. Manova's differences in leadership style and competition based on educational level

\begin{tabular}{|l|l|l|l|l|l|l|}
\hline $\begin{array}{l}\text { Dependent } \\
\text { Variable }\end{array}$ & $\begin{array}{l}\text { Type III Sum } \\
\text { of Squares }\end{array}$ & df & $\begin{array}{l}\text { Mean } \\
\text { Square }\end{array}$ & F & Sig. & $\begin{array}{l}\text { Partial Eta } \\
\text { Squared }\end{array}$ \\
\hline leadership style & 1.252 & 1 & 1.252 & 1.100 & 0.295 & 0.001 \\
\hline competition & 1.007 & 1 & 1.007 & 2.040 & 0.154 & 0.003 \\
\hline
\end{tabular}

Source: Own calculations.

Table 1 shows that there was no significant difference in leadership style ( $F=1.100$, $\operatorname{sig}=0.295, \mathrm{p}>0.05)$ and competition $(\mathrm{F}=2.040, \mathrm{sig}=0.154, \mathrm{p}>0.05)$ based on educational level with small effect differences (0.001 and 0.003 ) (Cohen, 1988). School students $(\mathrm{M}=5.71, \mathrm{SE}=0.05)$ had a leadership style similar to that of University students $(\mathrm{M}=5.63, \mathrm{SE}=0.07)$, as well as in terms of commitment, high school students $(\mathrm{M}=6.08, \mathrm{SE}=0.03)$ had a perspective on competence that was similar to that of University students $(\mathrm{M}=6.00, \mathrm{SE}=0.04)$.

\section{Influence of leadership style on leadership competencies according to the perspective of schoolchildren:}

Structural models show the relationships between unobservable (or latent) variables or the combination of several theoretical models built on theory. The proposed structural model was tested by determining the extent to which the proposed model was supported by covariance-variance data from the sample. In this study, the model proposed is the influence of leadership style on leadership competence.

The results of the SEM analysis in this study showed a model of hypothesized structure at, $\chi 2 / \mathrm{df}=4.78, \mathrm{RMSEA}=0.07, \mathrm{TLI}=0.90$, and $\mathrm{CFI}=0.91$. All evaluations yield the appropriate model. All loading factors for the leadership style and competency variables ranged from 0.59 to 0.93 . The factor loading value exceeds the required standard 0.50 (Hair et al., 2010). According to the school-age youth, leadership styles $(\beta=-0.12, p<0.05)$ and participation $(\beta=0.47, p<0.001)$ affected emotional competence. Participating in leadership style has a positive effect, while leadership style has a negative impact on emotional competence (Figure 2). 
Figure 2. Final Study Model

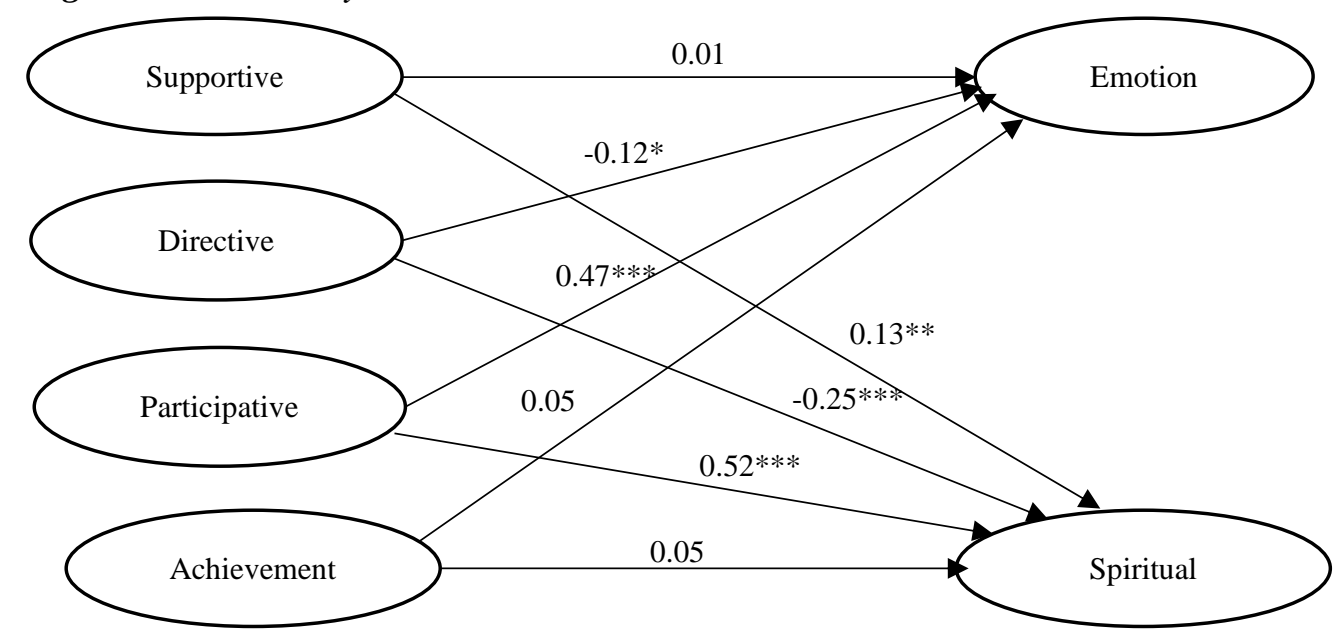

Note: *Significant at $0.05 ; * *$ Significant at $0.01 ; * * *$ Significant at 0.001

Source: Own calculations.

Supportive leadership styles $(\beta=0.01, \mathrm{p}>0.05)$ and achievement-oriented leadership styles $(\beta=0.05, p>0.05)$ did not have a significant effect on emotional competence. Subsequent leadership styles $(\beta=0.13, p<0.01)$, leadership $(\beta=-0.25, \mathrm{p}>0.001)$ and participation $(\beta=0.52, p<0.001)$ impacted on spiritual competence. Leadership styles support and participation positively, and leadership styles negatively affect spiritual competence. However, achievement-oriented leadership styles $(\beta=0.05, p>0.05)$ did not have a significant effect on spiritual competence.

\section{Influence of leadership style on leadership competence according to the perspective of University students:}

The results of the SEM analysis in this study showed the hypothesized structure model at, $\chi 2 / \mathrm{df}=4.93, \mathrm{RMSEA}=0.07, \mathrm{TLI}=0.91$, and $\mathrm{CFI}=0.93$. All evaluations yield the appropriate model. All loading factors for the leadership style and competency variables ranged from 0.76 to 0.97 . The factor loading value exceeds the required standard 0.50 (Gronemus et al., 2010).

According to the university students, leadership style supported $(\beta=-0.48, \mathrm{p}<0.001)$, leadership $(\beta=0.85, p<0.001)$, participation $(\beta=-0.09$, $p<0.001)$ and achievementoriented leadership style $(\beta=-0.11, \mathrm{p}<0.001)$ affects emotional competence. Next, leadership styles supported $(\beta=-0.47, \mathrm{p}<0.001)$, led $(\beta=0.84, \mathrm{p}<0.001)$, participation $(\beta=-0.13, \mathrm{p}<0.001)$ and achievement-oriented leadership styles $(\beta=$ $-0.06, \mathrm{p}<0.001)$ affects spiritual competence. Leadership style leads to a positive impact on emotional competence. While leadership styles support, participation, and achievement-oriented leadership styles negatively affect emotional and spiritual competence (Lionardo, 2019) (Figure 3). 
Figure 3. Final Study Model

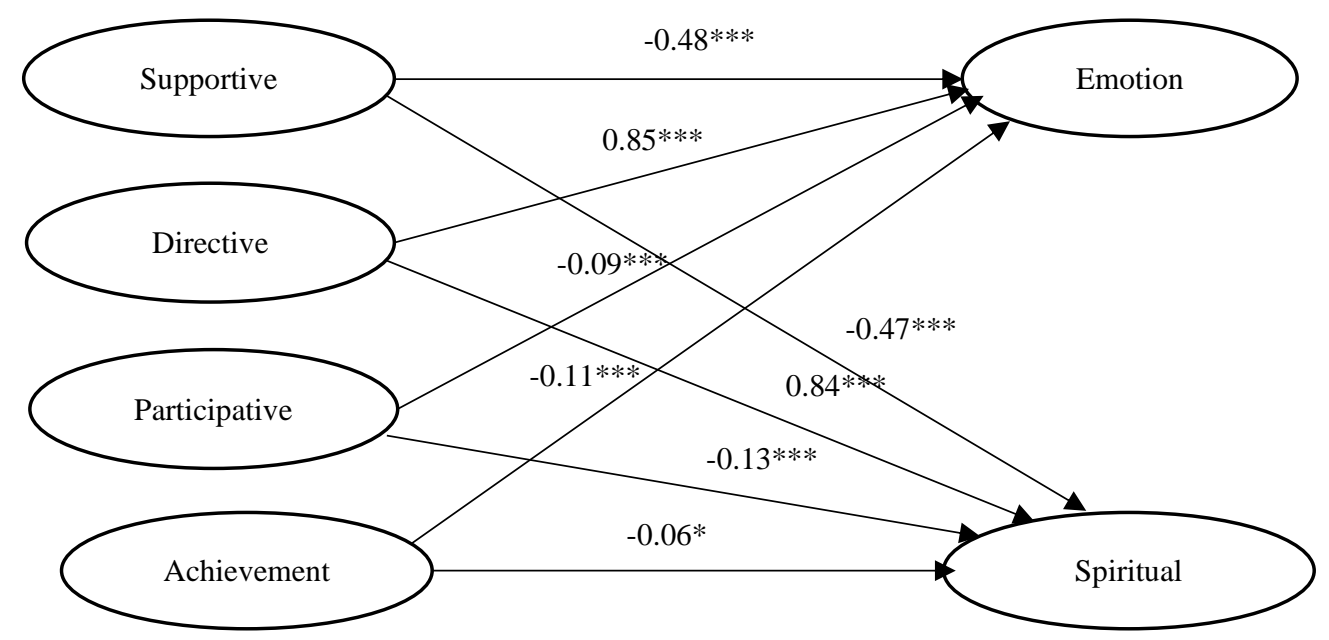

Note: *Significant at $0.05 ; * *$ Significant at $0.01 ; * * *$ Significant at 0.001

Source: Own calculations.

\section{Conclusion}

The findings of the study show that there is no significant difference in the style of leadership and commitment of the facilitator according to the perspective of Indonesian youth based on the level of education. This shows that Indonesian youth have a similar perspective on leadership style and competence. The findings show that youth with a level of education as students in the school where participation style leadership positively affects emotional competence. While leadership style leads to a negative impact on emotional competence.

The results of the study also show that from the perspective of youth studying at the university level, leadership style has a positive impact on emotional competence. While supportive leadership styles, participation, and achievement-oriented leadership styles negatively affect emotional and spiritual competence. Youth's integrity, political leadership style, and idealism score are high while their political concern score is at a moderate level to transformation within the society. This study has successfully demonstrated the influence of aspects of leadership style on leadership competence according to the standard of Youth Education in Indonesia. This study provides a reference for leaders to be able to refer to the leadership style of participation and to direct efforts to improve emotional competence.

\section{References:}

Bin Kamari, M.A., Bin Ahmad, A.R., Malek, J.A., Rahman, N.A., Lionardo, A. 2020. Social ecology and survival among multi-ethnic youths in urban areas. International Journal of Innovation, Creativity and Change 12(11), 71-82. 
Boukis, A., Koritos, C., Daunt, K.L., Papastathopoulos, A. 2020. Effects of customer incivility on frontline employees and the moderating role of supervisor leadership style. Tourism Management, 77, 103997.

Bouwmans, M., Runhaar, P., Wesselink, R., Mulder, M. 2017. Fostering teachers' team learning: An interplay between transformational leadership and participative decisionmaking? Teaching and Teacher Education, 65, 71-80.

Cheung, S.Y., Huang, E.G., Chang, S., Wei, L. 2020. Does being mindful make people more creative at work? The role of creative process engagement and perceived leader humility. Organizational Behavior and Human Decision Processes.

Creswell, J.W. 2012. Educational research: Planning, Conducting, and Evaluating Quantitative and Qualitative Research, pp. 650. Pearson Publishing.

Dumitriu, C., Timofti, I.C., Nechita, E., Dumitriu, G. 2014. The influence of the locus of control and decision-making capacity upon the leadership style. Procedia-Social and Behavioral Sciences, 141, 494-499.

Fitzsimons, G.M., Sackett, E., Finkel, E.J. 2016. Transactive goal dynamics theory: A relational goals perspective on work teams and leadership. Research in Organizational Behavior, 36, 135-155.

Fraenkel, J.R., Wallen, N.E. 2009. The nature of qualitative research. How to design and evaluate research in education, seventh edition. Boston, McGraw-Hill, 420.

Gronemus, J.Q., Hair, P.S., Crawford, K.B., Nyalwidhe, J.O., Cunnion, K.M., Krishna, N.K. 2010. Potent inhibition of the classical pathway of complement by a novel C1q-binding peptide derived from the human astrovirus coat protein. Molecular immunology, 48(13), 305-313.

Hashemy, S.H., Yousefi, M., Soodi, S., Omidi, B. 2016. Explaining human resource empowerment pattern and organizational excellence among employees of emergency of Guilan's University hospitals. Procedia-social and behavioral sciences, 230, 6-13.

Kearney, E., Shemla, M., van Knippenberg, D., Scholz, F.A. 2019. A paradox perspective on the interactive effects of visionary and empowering leadership. Organizational Behavior and Human Decision Processes, 155, 20-30.

Latunreng, W., Nasirin, C. 2019. Competitive advantage: Exploring the role of partnership with suppliers, customer relationship and information sharing as antecedents. International Journal of Supply Chain Management 8(6), 404-411

Lionardo, A., Alfitri, A., Awang, M.M., Ahmad, A.R., Khairuddin, K.F. 2019. Political concern and idealism as mediators for determining political leadership styles. International Journal of Innovation, Creativity and Change 7(10), 219-230

Nasirin, C. 2020. The role of nurses on the psychosocial quality of type 1 diabetes mellitus patients in a hospital in lombok, Indonesia. International Journal of Psychosocial Rehabilitation 24(5), 2507-2515

Nasirin, C., Asrina, H. 2020. Quality of nursing services and inpatient satisfaction. Management Science Letters 10(10), 2169-2174.

Pham, H., Kim, S.Y. 2019. The effects of sustainable practices and managers' leadership competences on sustainability performance of construction firms. Sustainable Production and Consumption, 20, 1-14.

Rehman, S.U., Shahzad, M., Farooq, M.S., Javaid, M.U. 2020. Impact of leadership behavior of a project manager on his/her subordinate's job-attitudes and job-outcomes. Asia Pacific Management Review.

Shao, J. 2018. The moderating effect of program context on the relationship between program managers' leadership competences and program success. International Journal of Project Management, 36(1), 108-120. 